\title{
JUURNAL.RU
}

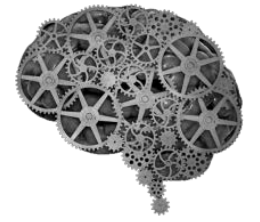

COMPANY GROUP "INTELLEKT"

\author{
Дуболазова С.Ю., Плотникова И.А. \\ Структурное подразделение «Детский сад №1》 \\ ГБОУ СОШ №5 г. Сызрани Самарской области РФ \\ Сызрань, Россия
}

doi: 10.18411/lj2016-8-2-04

idsp 000001: lj2016-17-2-04

\section{Педагогические условия повышения эффективности коррекционного воздействия на дошкольников, имеющих речевые нарушения}

Современная социально - экономическая ситуация ставит перед обществом немало сложных проблем. Медицинские, психолого педагогические и социологические исследования подтверждают ухудшение состояния здоровья детей дошкольного и школьного возраста, и этот факт становится предметом особого внимания. Еще Ж.Ж. Руссо сказал: «Идеал воспитания - это сочетание ума мудреца с силой и здоровьем атлета».

Огромную роль в обеспечении социального развития личности, сохранения психического, физического и нравственного здоровья детей играет образование, как целостная государственная структура. В соответствии сфедеральным законом «Об образовании в Российской Федерации» в статьях 2, 51 государственная политика в области образования основывается на принципах гуманистического характера, приоритете общечеловеческих ценностей, жизни и здоровья человека, свободного развития личности.

Государство большое внимание уделяет проблеме сохранения здоровой нации. В «Концепции модернизации Российского образования на период до 2020 года» определена стратегическая цель, заключающаяся в следующем: «Развивающемуся обществу нужны современно образованные, нравственные, предприимчивые люди, которые могут самостоятельно принимать ответственные решения в ситуации выбора, прогнозируя их возможные последствия, способны к сотрудничеству, отличаются мобильностью, динамизмом, конструктивностью, обладают развитым чувством ответственности 
за судьбу страны.» Обновлённое образование должно сыграть ключевую роль в сохранении нации, её генофонда, обеспечении устойчивого, динамичного развития российского общества - общества с высоким уровнем жизни, гражданско-правовой, профессиональной и бытовой культурой». Только здоровый ребёнок может гармонично развиваться и достигнуть выдвинутых требований.

Особое внимание должно быть сосредоточено на создании условий для полноценного включения в образовательное пространство и успешной социализации детей с ограниченными возможностями здоровья. Создание адаптивной образовательной среды - создание условий и помощи ребёнку в развитии, коррекции речевых нарушений в соответствии с его природосообразными способностями и возможностями, является актуальной задачей деятельности нашего структурного подразделения.

Учитывая самоценность дошкольного периода детства, на первый план выдвигаем развивающую функцию образования, обеспечивающую всестороннее развитие ребёнка, коррекцию речевого развития, становление полноценной личности. Только комплексное воздействие на ребёнка с речевыми нарушениями может дать успешную динамику речевого развития, его социальной адаптации.

Образовательная среда СП «Детский сад» состоит из следующих компонентов:

- взаимодействие участников педагогического процесса;

- развивающая предметно - пространственная среда;

- содержание дошкольного образования.

С учётом специфики развития ребёнка дошкольного возраста, имеющего речевые нарушения, большое значение в структуре образовательной среды придаём взаимодействию участников педагогического процесса. Его характер зависит от личностных и профессиональных качеств педагогических работников, индивидуальных и возрастных особенностей детей, педагогической культуры родителей. Поэтому в своей работе мы используем весь арсенал педагогических средств, формируем субъектную позицию каждого участника. Для этого выстраиваем личностно - ориентированную модель взаимодействия, особенностью которой является следующее: педагог, как субъект 
педагогического процесса, обеспечивает развитие детей, формируя у них знания, умения, навыки. Вместе с тем деятельность детей изменяет качество деятельности педагога, стимулирует его вести поиск нового содержания, форм и методов обучения, максимально соответствующих индивидуальным особенностям воспитанников. В результате происходит не только развитие каждого ребёнка, но и профессиональный и личностный рост педагога.

Важной стороной образовательного процесса в ДОО является взаимодействие педагогов и родителей воспитанников, в котором родители - не пассивные наблюдатели, а активные участники процесса. Формированию активной позиции родителей способствуют следующие свойства образовательного процесса:

- доступность информации о деятельности ДОО;

- обучение родителей методам и формам коррекционно развивающей работы с детьми, имеющими нарушения речи;

- направленность педагогов и администрации ДОО на повышение педагогической культуры родителей, изучение опыта семейного воспитания и использование его элементов в образовательном процессе;

- введение нетрадиционных форм сотрудничества.

Предметная среда является составным компонентом адаптивной среды. Исходное требование - коррекционно-развивающий характер среды. Она создаёт условия для творческой деятельности каждого ребенка, служит целям физического и психического развития и совершенствования, обеспечивает зону ближайшего развития, коррекцию речевых нарушений. При построении предметной среды обеспечиваем максимальный психологический комфорт для каждого ребёнка, создаём возможность для реализации его права на свободный выбор вида деятельности, способов ее осуществления и взаимодействия с окружающими.

Коррекционно - развивающая направленность предусматривает создание в ДОО единого речевого пространства.

Здоровьесберегающая и коррекционно - развивающая направленность предметной среды обеспечивает эмоциональное благополучие, сохранение психофизического здоровья ребенка, максимальное развитие его творческого 
потенциала, интеллектуальных возможностей, обеспечивает коррекцию речевых нарушений.

Следующим аспектом нашей работы является изменение содержания дошкольного образования.

Содержание развивающего образования предполагает отказ от методов, ориентированных преимущественно на усвоение ребёнкомопределённогообъёма знаний, умений и навыков. Знания, умения и навыки рассматриваются не как конечная цель образования, а как одно из самых важных средств дальнейшего развития и самовыражения ребёнка. Формирование у дошкольников способность к творческому применению знаний позволяют введение разных видов детской деятельности, стимулирующих собственную познавательную и творческую активность воспитанников: тренинги коммуникативных навыков, развивающие игры и упражнения, поисковые методы, элементы психогимнастики, эмоционально - стимулирующая гимнастика. Использование комплексных, интегрированных, доминантных, сюжетных, занятий по интересам помогает детям осознать практическую направленность знаний, их взаимосвязь, возможность использования в различных ситуациях; позволяет формировать у детей опыт их творческого применения. Интегрированность позволяет избежать излишней предметности в освоении содержания образования, недопустимого увеличения умственной и физической нагрузки на детей.

Интегрированность, разнообразие форм и методов, учет индивидуальных особенностей воспитанников способствует преодолению речевых нарушений.

Таким образом, деятельность СП «Детский сад №1» направлена на создание адаптивной образовательной среды, ориентированной на повышение эффективности коррекционного воздействия на дошкольников при речевых нарушениях. 